Rodrigo De Sales, Daniel Martínez-Ávila, \& José Augusto Chaves Guimarães. 2019. The Contribution of James Duff Brown to the Analytic-Synthetic Method: Comparisons with Otlet, Kaiser, and Ranganathan. NASKO, Vol. 7. pp. 1-6.

Rodrigo De Sales — rodrigo.sales.s@gmail.com, Federal University of Santa Catarina, Brazil

Daniel Martínez-Ávila — dmartinezavila@gmail.com, São Paulo State University, Brazil

José Augusto Chaves Guimarães — chaves.guimaraes@ unesp.br, São Paulo State University, Brazil

\title{
The Contribution of James Duff Brown to the Analytic- Synthetic Method: Comparisons with Otlet, Kaiser, and Ranganathan
}

\begin{abstract}
Considering that the analytic-synthetic method is still one of the main methodological approaches to knowledge organization, the present paper aims to highlight the contribution of James Duff Brown to the development of this method. We conducted a comparative analysis based on William James's pragmatism in order to investigate the convergences of Brown's work with other authors of the analytic-synthetic movement, namely Otlet, Kaiser, and Ranganathan. Our pragmatist analysis reveals that Brown developed a similar stance to the aforementioned authors based on the analysis and synthesis of subjects for knowledge organization.

\section{Introduction}

Considering that the analytic-synthetic method still has a prominent place in the theoreticalmethodological frameworks of knowledge organization, this paper aims to highlight the contribution of British librarian James Duff Brown (1862-1914) to the constitution of this important method in the context of Library and Information Science (LIS). Commonly associated with the studies of bibliographic classifications, and more specifically due to his Subject Classification (1906, 1914 and 1939), and famous for his significant work in the field of British Librarianship at the beginning of the 20th century (Sayers, 1955; Mills, 1960; Foskett, 1969; Foskett, 1974; Langridge, 1973, 1976), Brown was also one of the pioneers in the classification of subjects based on their constituent parts, that is, a classification based on the fundamental elements that compose complex subjects. This resulted in an effective influence of the Subject Classification on Bliss's Bibliographic Classification and Ranganathan's Colon Classification (Beghtol, 2004a, 2004b).

In this context, we aim to highlight some of the aspects addressed by Brown in his Subject Classification that show evidence of his convergence with important initiatives of the consolidation of the analytical-synthetic method, namely the analysis of information proposed by Paul Otlet in the development of the Universal Decimal Classification (UDC), the analysis and synthesis proposed by Julius Kaiser in his Systematic Indexing, and the faceted approach developed by S.R. Ranganathan. Svenonius (2000), Sales (2014) and Sales and Guimarães $(2016,2017)$ have been maintaining for years that both Kaiser and Ranganathan created together (intentionally or not), in the first half of the 20th century, the so-called analytic- synthetic method in knowledge organization. In this regard, Brown's contribution does not seem to have been explored enough, and this is the rationale of our comparative pragmatic analysis between the aspects worked by Brown, Otlet, Kaiser, and
\end{abstract}


Rodrigo De Sales, Daniel Martínez-Ávila, \& José Augusto Chaves Guimarães. 2019. The Contribution of James Duff Brown to the Analytic-Synthetic Method: Comparisons with Otlet, Kaiser, and Ranganathan. NASKO, Vol. 7. pp. 1-6.

Ranganathan in order to reveal the convergences between them and to place Brown among the originators of the analytic-synthetic approach.

\section{Background}

In a recent article, Sales et al. (2018) presented a historical overview of the Anglo-American tradition of knowledge organization and the convergent aspects of some of its main theorists on classification and subject indexing. In this article, the authors historically divided the knowledge organization field into the stages of subject description (bibliographic classifications), subject analysis (indexing I), and analysis and synthesis of subjects (indexing II), while highlighting the role of authors such as Harris, Dewey, Cutter, Kaiser, Otlet, and Ranganathan.

According to Clare Beghtol (2004a, 2004b), one of the few authors that specialized in Brown, his contributions seem to have been indeed overlooked in the academic debates related to the theoretical and practical developments of bibliographic classifications. Although the Subject Classification gained popularity in Great Britain, to the point of even being considered the official bibliographic classification of England in the first half of the twentieth century (Foskett, 1973), its theoretical contributions and merits are far from being properly studied in the knowledge organization literature. It is precisely this theoretical gap that the present paper aims to fill.

While analyzing the contribution of the Subject Classification to the evolution of bibliographic classification systems, Beghtol (2004a, 2004b) emphasized the role of Brown in the development of three classification schemes at the turn of the 19th century for the 20th century: the Quinn-Brown Scheme (1898), the Adjustable Classification (1898), and the Subject Classification $(1906,1914,1939)$. According to Beghtol, it was in this latter scheme in which Brown conceived fundamental contributions to the evolution of classification systems, in his efforts to address interdisciplinarity in subjects and using, as an example from the Universal Decimal Classification, signs of addition (+) to connect different subjects from classes of the same or different subjects, thus perfecting the ability to synthesize complex subjects. In addition, it also used a Categorical Table, "the list of elements that can be added to any division or subdivision in the schedules. These elements are preceded by a period (.) And can not be expanded or synthesized" (Beghtol, 2004b, p. 2). See, for instance, the example given by Barbosa (1969) for the "History of Commerce in Brazil" in which the subjects Commerce (L800), Brazil (W720), and History: categorical table (.10) would be synthesized in the following notation: L800W72.10.

Another aspect of Brown's classification that was highlighted by Beghtol (2004b) was to the "one-place classification", which consisted in prescribing a specific place to so-called "concrete" subjects, that is, a relevant place to the most substantial subjects. In Brown's view, concrete subjects should have fixed designations in order to gather all works on that subject together, regardless their point of view. Rather than trying to have different classes for every possible point of view on a subject, Brown decided to assign a single location for concrete subjects and gather all the works on that particular subject. For example, the subject "rose" could be approached from the perspective of Biology, Botany, Decoration, Horticulture, Poetry, etc., however, according to the Subject Classification, "rose" should always be 
Rodrigo De Sales, Daniel Martínez-Ávila, \& José Augusto Chaves Guimarães. 2019. The Contribution of James Duff Brown to the Analytic-Synthetic Method: Comparisons with Otlet, Kaiser, and Ranganathan. NASKO, Vol. 7. pp. 1-6.

located in Botany (Beghtol, 2004b). This view was conceived to address the problem of the physical location of documents, as the classificatory function of bibliographic classifications as fixed and relative location systems was also a main focus of Brown.

In the present paper, we focus on these three aspects developed by Brown: the gathering of different subjects of the same or different classes; the categorical table; and the one-place classification.

For the comparative analysis, we drew on William James's pragmatism (2018) as it was devised as a path to solve questions, or a way to approach and to understand problems. He expanded Charles Peirce's conception of pragmatism and applied it to concrete practical cases. James, in "The Pragmatic Method" (1904), expressed it as follows: "Suppose, in fact, that there are two different philosophical definitions, or propositions, or maxims, or what not, which seem to contradict each other, and about which men dispute. If, by assuming the truth of the one, you can foresee no conceivable practical consequence to anybody at any time or place, which is different from what you would foresee if you assumed the truth of the other, why then the difference between the two propositions is no real difference-it is only a specious and verbal difference, unworthy of further contention. Both formulas mean radically the same thing, although they may say it in such different words" (p. 674). In this sense, we aimed to understand how Brown, Otlet, Kaiser, and Ranganathan sought to develop their visions and differences within the development of the knowledge organization field. We also hold the objective of recognizing their relevance, the difference they made for knowledge organization, and how far the practical results of their conceptions of the analytic-synthetic method extended. In order to facilitate the comparison between the different aspects studied by these authors, we worked with two variables for analysis: the analytical dimension and the synthetic dimension. For the identification of the analytical and synthetic dimensions in Otlet, Kaiser, and Ranganathan we drew on the literature by Kaiser (1908, 1911), Ranganathan (1967, 1976), Dousa (2010), and Sales (2014).

\section{Results}

The results reveal that Otlet conducted his analysis of information based on the identification of smaller units of information contained in the subjects, namely: concepts, facts, and evidences. These units of information would be the most informative elements of the subject. Thus, the process of synthesis proposed by Otlet in the UDC included the link of different aspects of subjects (of the same class or not) with the plus sign (+) and the colon sign (:), complemented with common auxiliary facets that would serve to better specify the subjects, including time “...”, place (1/9), form (0/09), language $=\ldots$ and others.

Kaiser addressed the analytical dimension on the basis of the identification of the semantic categories "concrete" (terms commodities) and "process" (terms of action) contained in the specialized subjects of the business domain. Kaiser's synthesis (statement) envisaged the link between the terms referring to concretes and processes in a standardized subject statement, also complemented by the subcategory "country" and the expansion of the types "dates," "names," and others.

The analysis and synthesis of subjects in Ranganathan achieved a greater dynamicity due to the central role given to facets, later driven by the fundamental categories PMEST 
Rodrigo De Sales, Daniel Martínez-Ávila, \& José Augusto Chaves Guimarães. 2019. The Contribution of James Duff Brown to the Analytic-Synthetic Method: Comparisons with Otlet, Kaiser, and Ranganathan. NASKO, Vol. 7. pp. 1-6.

(Personality, Matter, Energy, Space, and Time). For Ranganathan, the analysis of a subject would be the extraction of the particular aspects that are characterized as such, that is, the extraction of the facets by the decomposition of the subject into its constituent elements. On the other hand, the synthesis of the subject would require to artificially recompose it on the same basis of the facets that had been identified, now called classificatory notations.

When comparing the analytic-synthetic movements of Otlet, Kaiser, and Ranganathan with the movement developed by Brown in his Subject Classification, we achieve the following scenario (Table 1):

Table 1: Comparison of the analytical and synthetic dimensions

\begin{tabular}{lll}
\hline \multicolumn{1}{c}{ Analysis } & \multicolumn{1}{c}{ Synthesis } \\
\hline Brown & $\begin{array}{l}\text { Identification of concrete subjects } \\
\text { (one-place classification) and } \\
\text { interdisciplinary aspects of subjects } \\
\text { (categorical table) }\end{array}$ & $\begin{array}{l}\text { Junction of subjects from the same class or } \\
\text { different classes and complementation with } \\
\text { interdisciplinary aspects }\end{array}$ \\
Otlet & $\begin{array}{l}\text { Identification of smaller information units } \\
\text { (concepts, facts, and evidences) }\end{array}$ & $\begin{array}{l}\text { Classificatory notation } \\
\text { Kaiser }\end{array}$ \\
$\begin{array}{ll}\text { Identification of the semantic } \\
\text { categories (concretes and processes) }\end{array}$ & $\begin{array}{l}\text { Junction of subjects from the same class or } \\
\text { different classes and complementation with } \\
\text { auxiliary facets }\end{array}$ \\
& $\begin{array}{l}\text { Verbal statement } \\
\text { Ranganathan }\end{array}$ & $\begin{array}{l}\text { Recomposition of subjects based on } \\
\text { categories and expansions } \\
\text { manifestthePMEST categories }\end{array}$ \\
\hline
\end{tabular}

Based on the table above, we observe that all Brown, Otlet, Kaiser, and Ranganathan developed views of knowledge organization based on the double movement of analysis and synthesis of subjects, proposing the decomposition and comprehension of the subjects in their constituent elements and their subsequent recomposition in standardized statements.

Adopting James's pragmatism (2018) as a reference for the analysis, we found that the four authors adopted the same knowledge organization stance to develop their schemas, tracing the path of analysis and synthesis of complex subjects. In this sense, we concluded 
Rodrigo De Sales, Daniel Martínez-Ávila, \& José Augusto Chaves Guimarães. 2019. The Contribution of James Duff Brown to the Analytic-Synthetic Method: Comparisons with Otlet, Kaiser, and Ranganathan. NASKO, Vol. 7. pp. 1-6.

that Brown, Otlet, Kaiser, and Ranganathan were key figures in the development of the fundaments of the analytic-synthetic movement.

\section{Conclusion}

Understanding that every effort to include more than one element of the subject of the document helps in the comprehension and constitution of the analytic-synthetic method, in this paper, we found that the identification of the fundamental elements (the informative elements) of different subjects was a common concern that was present as well as in the scheme of Brown as in the schemes of Otlet, Kaiser, and Ranganathan. Moreover, the way in which the four authors sought to develop their schemas was approached under the same pragmatic perspective of the analytic-synthetic movement.

Thus, we would like to conclude this paper by reiterating that Brown is one of the main authors responsible for the constitution of the analytic-synthetic method and should be placed side-by-side with other recognized theorists that helped to consolidate this methodological approach to knowledge organization. Further questions and directions for research would include the investigation of the relationships between authors and systems such as Brown/Subject Classification and Berwick Sayers, Brown/Subject Classification and Ranganathan's education in England, and the relation between Brown/Subject Classification and the different authors and views of the British Classification Research Group. These investigations would strengthen our argument and reaffirm our belief in Brown, Otlet, Kaiser, and Ranganathan as co-creators of the fundaments of the analytic-synthetic movement.

\section{References}

Barbosa, A.P. 1969. Teoria e prática dos sistemas de classificação bibliográfica [Theory and practice of systems for bibliographic classification]. Rio de Janeiro: Instituto Brasileiro de Bibliografia e Documentação.

Beghtol, C. 2004a. Exploring new approaches to the organization of knowledge: The Subject Classification of James Duff Brown. Library Trends 52, n.4: 702-718.

Beghtol, C. 2004b. James Duff Brown's Subject Classification and evaluation methods for classification systems. Arizona: The University of Arizona. Conference paper.

Dousa, T.M. 2010. Facts and frameworks in Paul Otlet's and Julius Otto Kaiser's theories of knowledge organization. Bulletin of the American Society for Information Science and Technology 36, n. 2: 1925 .

Foskett, A.C. 1969. The subject approach to information. London: Bingley.

Foskett, D.J. 1974. Classification and indexing in the social sciences. 2.ed. London: Butterworths.

James, W. 1904. The Pragmatic Method. The Journal of Philosophy, Psychology and Scientific Methods 1, n.25: 673-687

James, W. 2018. Pragmatism. Mineola, New York: Dover Publications.

Kaiser, J.O. 1908. The card system at the office. London: Vacher \& Sons, The Card System Series, 1.

Kaiser, J.O. 1911. Systematic indexing. London: Isaac Pitman \& Sons, The Card System Series, 2.

Langridge, D.W. 1973. Approach to classification: for students of librarianship. London: Bingley.

Langridge, D.W. 1976. Classification and indexing in the Humanities. London; Boston: Butterworth.

Mills, J. 1960. A modern outline of library classification. London, Chapman and Hall.

Ranganathan, S.R. 1967. Prolegomena to library classification. Bombay: Asia Publishing House. 
Rodrigo De Sales, Daniel Martínez-Ávila, \& José Augusto Chaves Guimarães. 2019. The Contribution of James Duff Brown to the Analytic-Synthetic Method: Comparisons with Otlet, Kaiser, and Ranganathan. NASKO, Vol. 7. pp. 1-6.

Ranganathan, S.R. 1976. Colon classification. 6. ed., 4. reimpr. Bombay; Calcutta; New Delhi; Madras; Lucknow; Bangalore; London; New York: Asia Publishing House.

Sales, R. 2014. A Organização da Informação de Julius Kaiser: o nascimento do método analíticosintético. [The organizaiton of information in Julius Kaiser: the birth of the analytical-syntetic method]. Saarbrücken: Novas Edições Acadêmicas/ OmniScriptum GmbH \& Co.

Sales, R. and J.A.C. Guimarães. 2016. A importância de Julius Kaiser para a organização do conhecimento: um estudo comparativo com as perspectivas de Cutter, Otlet e Ranganathan. [The importance of Julius Kaiser to the organization of knowledge: a compartaive study among Cutter, Otlet, and Ranganathan]. InCID: Revista de Ciência da Informação e Documentação 7: 43-65.

Sales, R. and J.A.C. Guimarães. 2017. O método analítico-sintético de Julius Kaiser: um pioneirismo para o tratamento temático da informação [The analytic-syntetic method of Julius Kaiser: a pioneer of the subject treatment of informaiton]. Transinformação 29: 125-139.

Sales, R. and D. Martínez-Ávila; Guimarães, J.A.C. 2018. Dialogical elements in Harris, Dewey, Cutter, Otlet, Kaiser, and Ranganathan: Theoretical convergences in the history of Knowledge Organization. Transinformação 30: 348-362.

Sayers, W.C.B. 1955. An introduction to library classification. 9. ed. London: Grafton.

Svenonius, E. 2000. The intellectual foundation of information organization. Cambridge: MIT Press. 